Captain Cook had good reason to remember the Great Barrier Reef, as also Captain Bligh. The reef, or more correctly the collection of reefs, outcrops and islands that stretch for 1,200 miles off the coast of Queensland, is no less difficult to navigate nowadays. But here amongst the maze of channels, bays and pools live the coral reef fishes that drew a riot of colour from Parkinson's brush (and perhaps some disbelief in Europe). George Coates, whose 178 colour drawings illustrate the present book, has managed to combine boldness with a certain restraint and delicacy. Together with the 319 half-tone figures (from many sources), the illustrations are quite sufficient for the kind of identification required by the amateur. In this version the author has eliminated keys and sacrificed 488 (out of 566) pages of text, adding one important virtue-a saving of nearly f6 sterling. The same 497 species are listed and are well indexed by scientific and vernacular names, but the species notes are reduced to exactly four telegraphic lines each. The nomenclature is in places outdated and neither authors nor dates are cited. However, this version is essentially an attempt to bring a useful book within the means of the amateur naturalist and fisherman, and in this it succeeds.

P. J. P. WHITEHEAD

British Freshwater Fishes, by M. E. Varley. Fishing News, 31s. 6d. The Trout, by W. E. Frost and M. E. Brown. New Naturalist monograph. Collins, 25s.

Both these books are important biological contributions to the immense literature on our fishes which, despite descriptive charm, has often lacked a scientific basis. Neither is intended or will do much to teach you how to catch fish (only one of the authors is an angler), yet both are invaluable in instructing the angler where he may look for what fish and how to manage his water.

The main theme of Dr. Varley's book, a publication of the Buckland Foundation, is the origin and development of the distribution of our freshwater fish. She considers that only the salmonids are truly native to Ireland, but that, apart from a few recent introductions, our English fish, at least in the southern and eastern parts of the country, may be regarded as indigenous.

Introductions of non-native species need caution. We have the best possible sporting fish in the brown trout, supported by the alien rainbow, which flourishes in artificial lakes, and we do not need the American speckled trout Salvelinus fontinalis in our rivers, where it has not successfully established itself. Certainly we do not want European predators like the pike-perch and the wels (a catfish), and naturalists should say to fishermen that the balance of our native fish fauna should not be further disturbed. Dr. Varley suggests an exception in tilapia, herbivorous fish which could be grown in heated waters and could not survive in the normal temperatures of our rivers or become competitive with our native species.

As one who has caught and eaten most of our freshwater fish, I agree with Dr. Varley that, apart from perch (excellent) and pike (eatable though to me not "delicious") and, of course, eels, the rest need special treatment to be palatable, and that, even in countries where they are most esteemed, the cyprinids taste of little except the sauce with which they are served. We neglect in our eels and perhaps in our perch a useful supplement to human food.

In The Trout, in which Dr. Varley under her maiden name collaborates with Dr. Frost, the complexity of the problems is admirably illustrated by the investigation of the effects of hard and soft waters upon the trout's biology. The chapters on the Physical Environment, Age and Growth and the Biological Environment are of absorbing interest, discussed with great thoroughness and skill of exposition. The chapter on "Trout and Man" should be carefully studied. Trends 
such as increasing warm effluents from industry into lakes and rivers, and growing pollution from sewage and other works, are telling against trout, with their high oxygen requirements, and those who fish for them, though some of these changes may be favourable to the more numerous and socially important group of anglers for coarse fish. But all anglers alike should realise that of all predators "the angler remains the most persistent and efficient, and he would do well to remember that in his attempts to conserve his prey". He should remember it also in his general relationship with and conduct towards all the wildlife of our rivers, lakes and ponds.

HURCOMB

\section{Birds of the Atlantic Islands, Volume III : A History of the Birds of the Azores, by David Armitage Bannerman and W. Mary Bannerman. Oliver \& Boyd, 84s. \\ Ireland's Birds, by Robert F. Ruttledge. Witherby, 30 s.}

The final volume of the Bannermans' trilogy adds the Azores to their previous work on the Canaries and Madeira. Both text and plates, by David Reid-Henry and the late George Lodge, are well up to the high standard for accuracy set by the two preceding volumes. Besides the usual systematic lists of breeding and migratory species, there are excellent essays on the birds of the individual islands in the group, some by Colonel Jose Agostinho and other local ornithologists. One notes with regret that the house sparrow, introduced into the islands by soldiers a few years ago, shows every sign of becoming established. The Azores being well out into the Atlantic, the presence of a number of American vagrants on their list is to be expected; nobody seems to have objected that they might have had an assisted passage. This is not a book for the pocket, but no birdwatcher visiting the Azores could afford to leave it at home.

Major Ruttledge was part-author of the authoritative Birds of Ireland, published in 1954. In the present book he summarises and brings up-to-date the great mass of knowledge about Irish birds that has accumulated since then, especially in the annual Irish Bird Reports, together with essays by local specialists such as Jimmy Deane. The main part of the book, however, is a straight systematic list which will be of the greatest value to both resident and visiting bird watchers; moreover it is small and light enough to carry comfortably in a knapsack. One notes that the inhibitions which still prevent British ornithologists from accepting as genuine those American vagrants which arrived before about 1950 do not prevent Irish ones from listing the slate-coloured junco shot in Co. Clare in May, 1905.

RICHARD FITTER

\section{The Bird Faunas of Africa and its Islands, by R. E. Moreau, Acade- mic Press, £5.}

Not many books deserve the epithet 'monumental', but here is one that does. It is built out of 20 years of field experience and intensifying study of two very different samples of Africa - the north-eastern margins of the Sahara and the forested Usambara-buttressed by contacts with (and stimulation of) every identifiable ornithologist in the Continent, and completed by 20 more years of research - the listed references comprise 386 titles, not counting the author's own very remarkable three dozen.

The presentation of this half-a-life's work is beautifully logical, and this, with the extensive use of tables to summarise the mass of data, prevents it from becoming too taxing on the digestion, despite the fact, for example, that some 800 of the 1,481 species credited to the region receive individual mention. This makes it easy to dip into or refer back to particular chapters with understanding 